\title{
OVLASTI NADZORNOG ODBORA U SVEZI S NADZOROM UPRAVE SPORTSKOG DIONIČKOG DRUŠTVA
}

\author{
UDK: 347. 725.036 \\ Primljeno: 20. 01. 2019. \\ Pregledni znanstveni rad
}

\begin{abstract}
U radu se obrađuje pitanje pravnog položaja i ovlasti nadzornog odbora sportskog dioničkog društva. Raspravlja se o širem kontekstu problematike nadzora vođenja poslova tih društava, posebice imajući u vidu da ona nemaju za cilj samo ostvarivanje dobiti već i postizanje sportskih ciljeva. Tako se razmatraju odredbe Zakona o sportu te posebice odgovarajuće odredbe Zakona o trgovačkim društvima kojima je uređeno to područje. Pitanje uloge nadzornog odbora u sportskom dioničkom društvu valja razmatrati ponajprije kroz odnos tog organa s upravom i glavnom skupštinom. Zakonodavac daje nadzornom odboru zadaću nadzora vođenja poslova te mu za ostvarenje tog cilja stavlja na raspolaganje ovlasti kojima se taj organ najviše približava samom vođenju poslova. Ipak, podjela zadaća uvjetovana organizacijskom strukturom tog tipa društva trebala bi onemogućiti nadzornom odboru da prisvoji zadaću vođenja poslova što pripada upravi. Naš Kodeks korporativnog upravljanja sadrži preporuke za nadzorni odbor, ali i preporuke o tome kakav bi trebao biti odnos između nadzornog odbora i uprave (sportskog) dioničkog društva. Posebna se pozornost $\mathrm{u}$ sportskim dioničkim društvima pridaje onim poslovima uprave koje ona smije poduzeti tek kad dobije suglasnost nadzornog odbora.
\end{abstract}

Ključne riječi: nadzorni odbor, ovlasti nadzornog odbora, odgovornost nadzornog odbora, suglasnost na odluke uprave, sportsko dioničko društvo

\section{UVOD}

Zbog velikog interesa javnosti za profesionalni sport, posebice nogomet, svjedoci smo pojave da je nerijetko pozornost usmjerena na nadzorne odbore sportskih dioničkih društava - sportskih klubova. Nadzornim odborima i njegovim članovima pripisuje se pravna moć koja im u stvarnosti zapravo i ne pripada. Dojam je sportske javnosti da bi nadzorni odbori sportskih dioničkih društava, kada okolnosti tako nalažu, trebali na neki način preuzeti funkciju i ovlasti uprave. Takva razmišljanja nam i ne trebaju biti neočekivana uzmemo li u obzir okolnost da je pitanje odnosa organa dioničkih društava jedna od najvažnijih tema statusnog trgovačkog prava o kojoj se raspravlja u znanosti, ali i u inozemnoj (doduše znatno manje) i u domaćoj sudskoj praksi. ${ }^{1}$ Posebice je tu riječ o odnosu uprave i drugih organa glede vođenja

1 Za naše pravo vidi: Barbić, J., Pravo društava: dioničko društvo, Organizator, Zagreb, 2010.; Barbić, J. et al., Nadzorni odbori - vodič kroz sustav korporativnog upravljanja, CROMA, Zagreb, 2006.; Gorenc, V. et al., Komentar Zakona o trgovačkim društvima, RRiF, Zagreb, 2008.; Slakoper, Z./ Buljan, V., 
Dr. sc. Ratko Brnabić: Ovlasti nadzornog odbora u svezi s nadzorom uprave sportskog dioničkog... Zbornik radova Pravnog fakulteta u Splitu, god. 56, 2/2019, str. 377.- 399.

poslova društva o čemu će biti više riječi u radu. Kada je riječ o sportskim dioničkim društvima, spomenutoj temi statusnog prava valja pridodati i pitanja koja proizlaze iz Zakona o sportu, ali i same prirode sporta i sportskog natjecanja.

U tom smislu, nadzorni odbori sportskih dioničkih društava imaju sljedeća obilježja. Prvo, Zakon o sportu (u nastavku: ZOS) ${ }^{2}$ kao poseban propis određuje da sportska dionička društva mogu imati samo dualistički ustroj organa. Taj propis upućuje na primjenu Zakona o trgovačkim društvima (u nastavku: ZTD), ${ }^{3}$ ali u ZOS-u nigdje se ne spominju upravni odbor niti izvršni direktor(i). S obzirom na to da je izmjenom ZTD-a koja je stupila na snagu 1. travnja 2008. postalo moguće za dionička društva pored dualističkog odabrati i monistički ustroj, a u međuvremenu Zakonodavac nije intervenirao s takvom izmjenom u Zakon o sportu, za zaključiti je da se kod sportskog dioničkog društva ne može odabrati monistički ustroj. ${ }^{4}$

Drugo, Zakon o sportu sužava krug osoba koje mogu postati članovi nadzornog odbora sportskih dioničkih društava, a istovremeno propisuje da ista osoba može biti član nadzornog odbora samo u jednom s.d.d.-u istoga sporta (zakonske prepreke za članstvo). Tako sportski sudac koji sudjeluje u organiziranju i vođenju sportskog natjecanja ne može biti član uprave ili nadzornog odbora s.d.d.-a. ${ }^{5}$ Osobe koje su

Trgovačka društva prema Zakonu o trgovačkim društvima, TEB, Zagreb, 2010. Za njemačko i austrijsko pravo društava koje nam je zakonodavni uzor vidi: Brandi, A., ,Ermittlungspflicht des Aufsichtsrates über die wirtschaftliche Situation des Unternehmens ,am Vorstand vorbei“?", Zeitschrift für Wirtschaftsrecht (ZIP), br. 4, 2000., str. 173.-176; Cahn, A., Aufsichtsrat und Business Judgment Rule, WM (Zeitschrift für Wirtschafts- und Bankrecht), br. 28, 2013., str. 1293-1305; Dittmar, F., „Informationsrechte des Prüfungsausschusses“, NZG, br. 6, 2014., str. 210..-212; Fleischer, H., „Die „Business Judgment Rule“: Vom Richterrecht zur Kodifizierung“, ZIP, br. 15, 2004., str. 685-692; Fleischer, H., „Gestaltungsgrenzen für Zustimmungsvorbehalte des Aufsichtsrats nach § 111 Abs. 4 S. 2 AktG“, BB, br. 15, 2013., str. 835843; Fonk, H. J., „Zustimmungsvorbehalte des AG-Aufsichtsrats“, ZGR, br. 1, 2006., str. 841-874; Goette, W; Habersack, M. (ur.), Münchener Kommentar zum Aktiengesetz, Band 2, 5. Auflage, Verlag C.H. Beck, München, 2019.; Götz, H., „Zustimmungsvorbehalte des Aufsichtsrates der Aktiengesellschaft", ZGR, br. 4, 1990., str. 633-656; Henze, H., „Leitungsverantwortung des Vorstands - Überwachungspflicht des Aufsichtsrats“, Betriebs Berater (BB), br. 5, 2000., str. 209-216; Henze, H., „Neuere Rechtsprechung zu Rechtsstellung und Aufgaben des Aufsichtsrats“, Betriebs Berater (BB), br. 4, 2005., str. 165-175; Hoffmann-Becking, M. (ur.), Münchener Handbuch des Gesellschaftsrechts, Bd. 4, 4. Auflage, Verlag C. H. Beck, München, 2015.; Hoffmann-Becking, M., „Das Recht des Aufsichtsrats zur Prüfung durch Sachverständige nach $\S 111$ Abs. 2 Satz 2 AktG“, Zeitschrift für Unternehmens und Gesellschaftsrecht (ZGR), br. 2, 2011., str. 136-154; Hölters, W., Aktiengesetz, 3. Auflage, Vahlen, München, 2017.; Hüffer, G./Koch, J., Aktiengesetz, 13. Auflage, Verlag C.H. Beck, München, 2018. Za englesko pravo vidi: Michie, J./ Oughton, C., „The Corporate Governance of Professional Football Clubs in England“, Corporate Governance: An International Review, Vol. 13, br. 4, 2005., str. 517-531. Za pregled stanja iz tog područja u Europi: Gammelsæter, H., Senaux, B., The Organisation and Governance of Top Football Across Europe: An Institutional Perspective, Routledge, London, 2011.; Gulbrandsen A. M. / Gulbrandsen, C. M., Valuation of Football Players, A Complete Pricing Framework, Norges Handelshøyskole, Bergen, 2011.

2 Zakon o sportu (Narodne novine 71/2006, 150/2008, 124/2010, 124/2011, 86/2012, 94/2013, $85 / 2015,19 / 2016)$.

3 Zakon o trgovačkim društvima (Narodne novine 111/1993, 34/1999, 121/1999, 52/2000, 118/2003, 107/2007, 146/2008, 137/2009, 111/2012, 125/2011, 68/2013, 110/2015).

4 Zakonodavac je u Zakon o sportu od tada do danas intervenirao 7 puta (Narodne novine 150/2008, $124 / 2010,124 / 2011,86 / 2012,94 / 2013,85 / 2015,19 / 2016)$ pa je time jasno pokazao da tu nije riječ o nenamjernom propustu. Usp. Barbić, J., o. c. u bilj. br. 1, str. 666. Također vidi Slakoper, Z./ Buljan, V., o. c. u bilj. br. 1, str. 437, gdje autor navodi niz argumenata koji govore u prilog analognoj primjeni odredbi o monističkom ustroju organa d.d.-a na d.o.o.

5 Vidi čl. 11. st. 2. ZOS-a. 
članovi nadzornog odbora s.d.d.-a ne mogu istovremeno biti članovi tijela sportskog kluba-udruge za natjecanje ako je riječ o klubovima istog sporta. ${ }^{6}$ Članovi uprave i nadzornog odbora s.d.d.-a ne mogu biti niti osobe koje su u posljednje tri godine pravomoćno kažnjene za kaznena djela ili prekršaje u sportu i u vezi sa sportom, kao ni osobe pravomoćno osuđene na kaznu zatvora u trajanju od najmanje šest mjeseci za neko od kaznenih djela počinjenog s namjerom, a nije primijenjena uvjetna osuda, osobe koje su članovi sportskih klubova-udruga za natjecanje istoga sporta, osobe koje su članovi tijela s.d.d.-a istoga sporta, osobe koje svojim djelovanjem mogu neposredno utjecati na sustav natjecanja u odgovarajućem sportu, a osobito sportaši, menadžeri u sportu, kao i osobe koje su to bile u razdoblju posljednjih godinu dana, članovi pravnih osoba koje obavljaju djelatnost organiziranja sportskih kladionica, kao i osobe koje su to bile posljednje tri godine, članovi tijela pravnih osoba koje obavljaju djelatnost organiziranja sportskih kladionica, kao i osobe koje su to bile te osobe koje s menadžerima u sportu i članovima pravnih osoba te članovima tijela pravnih osoba koje obavljaju djelatnost organiziranja sportskih kladionica djeluju zajednički. ${ }^{7}$ Uz to, članovi nadzornog odbora sportskih dioničkih društava mogu podmirivati svoje novčane tražbine prema tim društvima koje proizlaze iz kredita, zajmova ili drugih pravnih poslova tek nakon podmirenja dospjelih obveza prema ostalim vjerovnicima. ${ }^{8}$

Treće, neke od djelatnosti iz predmeta poslovanja sportskih dioničkih društava ne uklapaju se u ,tipične“ gospodarske djelatnosti. ${ }^{9}$ Jedna od takvih djelatnosti jest sudjelovanje u sportskim natjecanjima. ${ }^{10}$ Stoga se od organa tih društava očekuje da u okviru svojih ovlasti doprinose i ostvarenju unaprijed definiranih sportskih ciljeva, a ne isključivo ostvarenju dobiti. Iako to vrijedi prvenstveno za upravu, nadzorni odbor također može doći u situaciju da treba zauzeti stav ili dati mišljenje o nekom pitanju iz područja vođenja poslova (posebice iz sportske domene), a to će biti onda kada je statutom, poslovnikom o radu ili pojedinačnim aktom (odlukom) nadzornog odbora predviđeno da je uprava za neki posao iz svoje nadležnosti dužna ishoditi prethodnu suglasnost nadzornog odbora.

Četvrto, u ekonomskom smislu poslovanje sportskih dioničkih društava ima posebna obilježja. Kod tih društava teže je procijeniti prosječan trošak kapitala nego kod drugih društava jer trošak kapitala ne stvara dobit za dioničare. Ta društva imaju visok rizik poslovanja, rizik ostvarenja dobrog sportskog rezultata, ali i rizik

6 Vidi čl. 27. st. 3. ZOS-a.

7 Vidi čl. 38. st. 2. ZOS-a.

8 Vidi čl. 25. ZOS-a.

9 Vidi čl. 1. ZTD-a.

10 Sportske lige i klubovi koji u njima sudjeluju stvaraju zajednički proizvod čija vrijednost ovisi o učinkovitoj suradnji između klubova koji se natječu. Klubovi pristaju sudjelovati u natjecanju te prihvaćaju pravila natjecanja jer sudjelovanje u stvaranju zajedničkog proizvoda dovodi do rasta ekonomske vrijednosti onih proizvoda koje svaki klub stvara i pojedinačno. Ekonomski rezultat cijelog sportskog natjecanja (lige i njezinih članova - klubova) bit će maksimalan kada postoji određeni stupanj ravnoteže - izjednačenosti klubova po kvaliteti - što onda ishod samog natjecanja čini neizvjesnim i time zanimljivim za gledatelje. Tako Michie, J./ Oughton, C., o. c. u bilj. br. 1, str. 517. 
pogrešne procjene kod sklapanja ugovora s igračem, a najveću imovinsku vrijednost predstavlja im nematerijalna imovina (igrači). ${ }^{11}$

Iako nadzorni odbor raspolaže pravnim sredstvima kojima može znatno utjecati na upravu kao organ društva, nema dvojbe da upravi pripada ovlast vođenja poslova sportskog kluba ustrojenog kao dioničko društvo. Nadzorni odbor nema „,izvršnu vlast" u sportskom dioničkom društvu. Uprava je dužna poduzeti sve što je potrebno za povećanje imovine s.d.d.-a kao i za ostvarenje zacrtanih sportskih ciljeva te mora poduzeti radnje za otklanjanje bilo kakve štete koja bi mogla nastati takvom društvu. Uprava sportskog dioničkog društva mora pravovremeno prepoznati opasnosti koje bi mogle ugroziti njegovu opstojnost, ali i one okolnosti koje utječu na sposobnost društva da ostvaruje sportske i ekonomske ciljeve te je dužna poduzeti odgovarajuće mjere. Uprava je dužna izvješćivati nadzorni odbor o poslovnoj politici, rentabilnosti poslovanja i tijeku poslova, a nadzorni odbor može zahtijevati od uprave da ga izvješćuje i o drugim pitanjima od značaja za poslovanje tog sportskog dioničkog društva.

U sklopu zadaće nadzora rada uprave, nadzorni odbor može, između ostaloga, pregledavati i ispitivati poslovne knjige i dokumentaciju društva, blagajnu, vrijednosne papire i druge stvari. Istodobno, nadzorni odbor mora svojim nadzorom osigurati da svaki član uprave postupa u skladu sa svojim ovlastima. Neposredni kontakt s upravom nužan je jer nadzorni odbor mora raspolagati svim informacijama od značaja kako bi obavio svoje zadaće. Ako to zahtijevaju konkretne okolnosti (primjerice nastupi li kriza kluba), nadzor će se obavljati neprekidno.

Poseban pojavni oblik prava nadzora koji se najčešce koristi kao argument da nadzorni odbor prisvaja zadaće uprave jest ovlast nadzornog odbora u svezi s poslovima za čije se obavljanje traži njihova prethodna suglasnost. Svako dioničko društvo statutom može utvrditi krug poslova koje zbog njihova značaja uprava može poduzeti samo uz prethodnu suglasnost nadzornog odbora. Međutim, ta suglasnost ne smije prerasti u pravo nadzornog odbora na davanje obvezujućih uputa upravi čime bi taj organ faktički preuzeo vođenje poslova društva.

\section{VOĐENJE POSLOVA KAO PREDMET NADZORA}

Nadzorni odbor nadzire vođenje poslova društva. ${ }^{12}$ Istovjetan pojam ,vođenje poslova društva" nalazi se u odredbi kojom se uređuje glavna zadaća uprave,${ }^{13} \mathrm{pa}$ iz toga proizlazi zaključak da nadzorni odbor nadzire poslove koji spadaju u nadležnost uprave. Nadzorni odbor može nadzirati sve mjere uprave koje spadaju u vođenje

11 Procjenom vrijednosti igrača bavi se ekonomska znanost te se razrađuju različite metode za tu procjenu. Detaljnije o tome Gulbrandsen A. M. / Gulbrandsen, C. M., Valuation of Football Players, A Complete Pricing Framework, Norges Handelshøyskole, Bergen, 2011., str. 64. i dalje.

Dostupno na https://brage.bibsys.no/xmlui/handle/11250/169019, pregledano 5. II. 2019.

12 Vidi čl. 263. st. 1. ZTD-a.

13 Vidi čl. 240. ZTD-a. Usp. za njemačko pravo Koch, J., o. c. u bilj. br. 1, § 77 Rdn. 3. i § 111 Rdn. 2. 
poslova društva. Pri tome spomenuti organ zauzima stav o pojedinim pitanjima, a može zatražiti dodatna objašnjenja u svezi s planiranim ili već poduzetim poslovima ali i u svezi s poslovima koje je uprava propustila poduzeti. ${ }^{14}$ Dužnost nadzora odnosi se samo na one mjere uprave koje spadaju u vođenje poslova, ne i na druge ovlasti uprave kao što su npr. pravo i dužnost uprave na sazivanje glavne skupštine ${ }^{15}$ te pravo na pobijanje odluka glavne skupštine. ${ }^{16}$

Nadzorna aktivnost nadzornog odbora u pravilu je ograničena na ispitivanje i pregled različitih izvješća uprave te na nadzor odluka uprave, a odvija se na sjednicama nadzornog odbora. ${ }^{17}$ Stoga nadzorni odbor nije dužan detaljno pratiti provedbu tih odluka niti je dužan - ako za to ne postoji opravdan razlog - detaljno pratiti cjelokupno vođenje poslova. ${ }^{18}$

Istodobno, popis tema o kojima je uprava dužna izvješćivati nadzorni odbor, ali i glavnu skupštinu, daje okvir u kojem nadzorni odbor obavlja zadaću nadzora što ne sprečava taj organ da ispituje i pregledava sve dokumente i druge stvari društva. ${ }^{19}$ Uprava mora izvješćivati nadzorni odbor društva o poslovnoj politici i o drugim načelnim pitanjima budućeg vođenja poslova te odstupanjima od prijašnjih predviđanja $s$ navođenjem razloga za to, o rentabilnosti poslovanja društva i rentabilnosti upotrebe vlastitog kapitala, tijeku poslova, napose prihoda i stanja društva te o poslovima koji bi mogli biti od velikog značenja za rentabilnost poslovanja i za likvidnost društva. ${ }^{20}$

Nadzornom odboru uprava je dužna podnositi izvješća periodično i prigodno, na zahtjev i bez posebnog zahtjeva odnosno po samom ZTD-u, a u svakom slučaju izvješća moraju biti sastavljena savjesno i istinito te podnesena pravodobno i (u pravilu) pisanim putem. ${ }^{21}$ Uprava je dužna izvješćivati nadzorni odbor o poslovnoj politici najmanje jednom godišnje, ali ako se stanje izmijeni ili to nalažu konkretne okolnosti, onda bez odgađanja, o drugim načelnim pitanjima budućeg vođenja poslova te odstupanjima od ranijih predviđanja s navođenjem razloga za to, o rentabilnosti poslovanja društva a napose rentabilnosti upotrebe vlastitoga kapitala na sjednici nadzornog odbora na kojoj se raspravlja o godišnjim financijskim izvješćima, o tijeku poslova, napose prihoda i stanja društva, najmanje tromjesečno a o poslovima koji bi mogli biti od velikog značaja za rentabilnost poslovanja i za likvidnost društva pravodobno kako bi nadzorni odbor mogao o njima zauzeti stav. ${ }^{22}$

$14 \mathrm{~S}$ druge strane, potrebno je naglasiti da ponašanja uprave koja se sastoje u propuštanju i trpljenju ne spadaju u mjere za koje je potrebna prethodna suglasnost uprave o čemu će biti više riječi poslije u radu.

15 Vidi čl. 251., čl. 277. st. 1. i 2. ZTD-a.

16 Vidi čl. 362. toč. 4. ZTD-a.

17 Vidi čl. 264. - 267. ZTD-a.

18 Tako Habersack, M., o. c. u bilj. br. 1, § 111, Rdn. 22.

19 Vidi čl. 250, 250.a, 250.b ZTD-a.

20 Vidi čl. 250. st. 1. ZTD-a.

21 Slakoper, Z.; Buljan, V., o. c. u bilj. br. 1, str. 357.

22 Izvješća se redovito podnose predsjedniku nadzornog odbora, a o primitku izvješća on je dužan obavijestiti članove nadzornog odbora najkasnije na prvoj sjednici nadzornog odbora koja se održava 
Ako ima mnogo tema za razmatranje i odlučivanje, a neke su i vrlo složene i za društvo od bitne važnosti, tada treba održavati sjednice nadzornog odbora kada god to nalažu interesi društva.

Kod analize financijskog poslovanja svakako valja polaziti od općeprihvaćenih kriterija dobrog poslovanja koji se uobičajeno navode u obliku dvaju obilježja: uspješnost i sigurnost. Da bi neko poslovanje bilo ocijenjeno pozitivno, potrebno je da njegovi pokazatelji istodobno potvrđuju uspješno, ali i sigurno poslovanje. Pokazatelji uspješnosti uobičajeno uključuju pokazatelji ekonomičnosti, profitabilnosti i investiranja, a pokazatelji sigurnosti su pokazatelji likvidnosti i zaduženosti. Pokazatelji aktivnosti dijelom se odnose na uspješnost, a dijelom na sigurnost poslovanja. Valja naglasiti da svako društvo ima specifičnu „težinu" svakog od pokazatelja, ali se može istaknuti da oba kriterija (uspješnost i sigurnost) trebaju biti zadovoljena u optimalnom odnosu, što se uspoređuje s prosjekom pripadajuće djelatnosti, ali i teorijski utvrđenim odnosima. Naprimjer, poslovanje poduzeća koje ostvaruje zavidnu (natprosječnu) ekonomičnost (odnos prihoda i rashoda), uz previsoku zaduženost (s preniskim koeficijentima likvidnosti), s teškoćama u podmirenju obveza, svakako ne može biti ocijenjeno visokom ocjenom jer ne zadovoljava kriterij sigurnosti. ${ }^{23}$

U okviru svojih redovitih nadzornih zadaća, nadzorni odbor može pregledavati $i$ ispitivati poslovne knjige i dokumentaciju društva, blagajnu, vrijednosne papire i druge stvari, a u tu će svrhu taj organ primjerice nadzirati računovodstvo, sustav unutarnje kontrole, sustav upravljanja rizicima itd. Nadzorni odbor može od uprave zahtijevati da ga izvješćuje i o drugim pitanjima koja su od značenja za poslovanje i stanje društva, što praktično znači da može tražiti izvješćivanje o svemu u društvu i u vezi s njim. Uprava je primarni izvor informacija nadzornom odboru i zbog toga je od značaja da između spomenutih organa odnosno njihovih članova postoji odnos povjerenja jer su upućeni na suradnju bez obzira na to što u s.d.d.-u obavljaju drugačije zadaće. Kao što je sama uprava kao organ dužna podnijeti izvješća nadzornom odboru, tako i nadzorni odbor svoje zahtjeve u svezi s obavještavanjem upućuje u pravilu samo upravi. Nadzorni odbor u pravilu neće informacije zahtijevati izravno od zaposlenika. ${ }^{24}$ Izravno postavljanje upita zaposlenicima društva podređenima upravi dolazi u obzir samo u izuzetnim slučajevima jer bi takav zahtjev nadzornog odbora bio suprotan ustroju i hijerarhiji organa dioničkog društva. Uprava je ta koja vodi poslove društva pa mora kontrolirati i rad zaposlenika društva. Međutim, ako postoji opravdana sumnja u nedopušteno ponašanje članova uprave (povreda dužnosti - primjerice davanje netočnih/neistinitih podataka u izvješćima) ili je nastupila kriza društva, tada je opravdana izravna komunikacija nadzornog odbora

nakon primitka izvješća. Svaki član nadzornog odbora ima pravo zahtijevati uvid u izvješće i pisani primjerak izvješća. Ibid., str. 357. Usp. Barbić, J., Pravo društava: dioničko društvo, o. c. u bilj. br. 1, str. 720.

23 Barbić, J. et al., o. c. u bilj. br. 1, str. 218.

24 Hambloch-Gesinn, S., o. c. u bilj. br. 1, § 111 Rdn. 22. 
i npr. službenika koji je u društvu zadužen za korporativnu usklađenost. ${ }^{25} \mathrm{~S}$ obzirom na to, nadzorni odbor nije dužan nadzirati aktivnosti zaposlenika, čak ni kada je prema sistematizaciji radnih mjesta riječ o višim voditeljima. Ovo vrijedi i ako s.d.d. ima odjele ili poslovne jedinice, a voditelji pojedinih odjela obavljaju poslove koji spadaju u poslovodstvo, ali nisu članovi uprave. ${ }^{26} \mathrm{Uz}$ to, nema prepreke da nadzorni odbor angažira zaposlenike s.d.d.-a ako je riječ o stručnjacima koji ih mogu savjetovati u svezi s nekim pitanjem. Kada nadzorni odbor pribavlja informacije drugim kanalima a ne u komunikaciji s upravom, tim se pravom mora koristiti obazrivo da takvo ponašanje ne bude protumačeno kao gubitak povjerenja u rad uprave što se može negativno odraziti na vrijednost dionica tog društva na uređenom tržištu. Stoga tu treba pažljivo razmotriti pozitivne, ali i moguće negativne učinke.

Ovlast nadzora vođenja poslova nadzorni odbor ostvaruje putem brojnih pravnih sredstava koje mu Zakonodavac stavlja na raspolaganje. Tako nadzorni odbor imenuje i opoziva članove uprave ${ }^{27}$ predlaže glavnoj skupštini imenovanja novog nadzornog odbora, ${ }^{28}$ donosi odluke kojima se ograničava uprava u vođenju poslova, ${ }^{29}$ utvrđuje kriterije i određuje primanja članova uprave, ${ }^{30}$ daje suglasnost članovima uprave da, bez obzira na načelo zabrane utakmice, mogu obavljati određene poslove, odnosno biti članom uprave drugih društava ili članom društava osoba, ${ }^{31}$ daje zajmove članovima uprave, te članovima nadzornog odbora i prokuristima i članovima njihovih užih obitelji, ${ }^{32}$ zahtijeva od uprave da ga izvješćuje o svim pitanjima koja su od značenja za poslovanje i položaj društva, ${ }^{33}$ zastupa društvo prema članovima uprave, ako dođe do spora između uprave i društva, ${ }^{34}$ saziva glavnu skupštinu društva kada je to potrebno radi dobrobiti društva običnom većinom glasova, ${ }^{35}$ podnosi glavnoj skupštini pisano izvješće o obavljenom nadzoru u kojem iznosi svoje stajalište o prijedlogu uprave glede pokrića gubitaka i podjele dobitka, ${ }^{36}$ odlučuje o imenovanju svojih članova za privremene zamjenike članova uprave koji nedostaju, ${ }^{37}$ donosi poslovnik o svom radu, ali i o radu uprave, ${ }^{38}$ daje prethodnu

25 Nadzorni odbor može pregledati sve poslovne prostorije, proizvodne pogone, laboratorije tog društva pa čak i one koje se nalaze u inozemstvu. Nadzorni odbor ima pravo pregledati i proizvodnu dokumentaciju te se upoznati i s proizvodnim procesom. Dittmar, F., o. c. u bilj. br. 1, str. 212.

26 Habersack, M., o. c. u bilj. br. 1,§ 111, Rdn. 21.

27 Vidi čl. 244. ZTD-a.

28 Vidi čl. 280. ZTD-a.

29 Vidi čl. 242. st. 2. ZTD-a.

30 Vidi čl. 247. ZTD-a.

31 Vidi čl. 248. ZTD-a.

32 Vidi čl. 249. st. 1. i čl. 271. st. 1. ZTD-a.

33 Vidi čl. 250. st. 6. ZTD-a, čl. 250.a i 250.b ZTD-a.

34 Vidi čl. 268. ZTD-a.

35 Vidi čl. 263. st. 4. ZTD-a.

36 Vidi čl. 263. st. 3. ZTD-a.

37 Vidi čl. 261. st. 2. ZTD-a.

38 Vidi čl. 240. st. 3. ZTD-a. 
suglasnost upravi za obavljanje određenih vrsta poslova ${ }^{39}$ i daje nalog revizoru za ispitivanje godišnjih financijskih izvješća društva. ${ }^{40}$ Autonomija uređenja odnosa u s.d.d.-u ograničena je činjenicom da je taj tip društva uređen pretežno prisilnim odredbama. ${ }^{41}$ Statutom društva ovlasti nadzornog odbora moguće je samo u nekim pitanjima suziti (primjerice odredbom da uprava sama donosi poslovnik o radu) ili proširiti (navođenjem niza poslova uprave za koje je potrebna suglasnost nadzornog odbora). ${ }^{42}$ Dopušteno je nadzornom odboru također pridodati neke funkcije i zadaće koje Zakonodavac ne smatra važnima za funkcioniranje i obavljanje zadaća tog organa pa se statutom ili poslovnikom o radu npr. može dati pravo nadzornom odboru da imenuje svog počasnog predsjednika. ${ }^{43}$

Zadaća nadzornog odbora nije samo obavljanje kontrole zakonitosti mjera koje poduzima uprava, već nadzorni odbor mora provjeriti primjerenost i opravdanost odluka uprave. $\mathrm{U}$ tom smislu, nadzorni odbor mora ispitati postupa li uprava u skladu sa svojim dužnostima, a posebice mora ispitati postupa li uprava s pozornošću urednog i savjesnog gospodarstvenika. ${ }^{44}$ Kod ispunjenja svojih zadaća nadzorni odbor nije ograničen samo na provjeru postupanja uprave u skladu s njihovim dužnostima, već će nerijetko zauzeti stav o pojedinim mjerama uprave npr. u svezi s provedbom poslovne politike s.d.d.-a.

Prema preporuci našeg Kodeksa korporativnog upravljanja, ${ }^{45}$ nadzorni odbor upravi treba davati jasne ciljeve koji moraju biti dogovoreni i formalizirani. U mjeri u kojoj je to moguće, ti ciljevi trebaju biti mjerljivi. Međutim, ne smije se zanemariti postizanje kvalitativnih ciljeva. Rad uprave treba periodično procjenjivati u odnosu na postizanje ciljeva. Nadalje, nadzorni odbor dužan je surađivati s upravom i pravodobno donositi sve odluke te o njima izvješćivati upravu, a uprava je dužna pravodobno i cjelovito izvješćivati nadzorni odbor o svim činjenicama i okolnostima koje mogu biti od utjecaja na poslovanje, financijski položaj i stanje imovine trgovačkog društva, odnosno njegovih društava kćeri te surađivati s

39 Vidi čl. 263. st. 5. ZTD-a. Radi li se o koncernu, nalog daje nadzorni odbor koncerna.

40 Vidi čl. 263. st. 2. reč. 3. ZTD-a.

41 Detaljnije vidi Barbić, J., o. c. u bilj. br. 1, str. 659.

42 Posebice ovo potonje zapravo nije proširivanje ovlasti nadzornog odbora jer već prema čl. 263. st. 5. ZTD-a može se autonomnim aktom društva odrediti da se određene vrste poslova mogu obavljati samo uz prethodnu suglasnost nadzornog odbora. Kada se za konkretno društvo odredi krug tih poslova, nadzorni odbor će se u pravilu usmjeriti na njih iako opća dužnost nadzora pretpostavlja da nadzorni odbor kontrolira i poslove koji tu nisu navedeni.

43 Vrijedi pripomenuti da počasni predsjednik neće postati članom nadzornog odbora u smislu obavljanja zakonskih zadaća tog organa. Habersack, M., o. c. u bilj. br. 1, § 111, Rdn. 6.

44 Vidi čl. 252. ZTD-a.

45 Kodeks korporativnog upravljanja trgovačkim društvima u kojima Republika Hrvatska ima dionice ili udjele (Narodne novine 132/2017, 52/2018, u daljnjem tekstu: Kodeks) predstavlja skup načela poslovnog profesionalnog ponašanja i dobrih običaja kojima se jača korporativna i vlasnička odgovornost provođenjem standarda ponašanja u svrhu postizanja dobrobiti za sve sudionike. Nema prepreka da se barem neka od tih pravila ne ugrade u statute sportskih dioničkih društava kao i u poslovnike o radu uprava/nadzornih odbora tih društava, bilo izričitim navođenjem pojedinih pravila ili pozivanjem na primjenu Kodeksa. Također, spomenuta pravila moguće je ugraditi i u tekst menadžerskih ugovora koje članovi uprave sklapaju sa sportskim dioničkim društvima. Naime, pokazalo se da zbog komercijalizacije sporta pitanje „dobrog upravljanja“ profesionalnim sportskim klubovima postaje sve značajnije. 
Dr. sc. Ratko Brnabić: Ovlasti nadzornog odbora u svezi s nadzorom uprave sportskog dioničkog... Zbornik radova Pravnog fakulteta u Splitu, god. 56, 2/2019, str. 377.- 399.

nadzornim odborom. Uprava i nadzorni odbor dužni su uvijek postići sporazum glede strateških odrednica trgovačkog društva i provođenja strateških ciljeva te ne smiju zbog nesuradnje dovesti u pitanje stabilnost poslovanja ili donošenje odluka potrebnih za uredno, pravovremeno i odgovorno poslovanje trgovačkog društva. ${ }^{46}$

Nadzorni odbor u svojoj domeni rada mora postupati s pozornošću urednog i savjesnog gospodarstvenika. Taj stupanj pozornosti odnosi se prvenstveno na dužnost nadzora, ali se pri tom ne smije zaboraviti da je članstvo u nadzornom odboru za te osobe sporedan posao. Budući da nadzorni odbor nije zadužen za poslovodstvo, već za nadzor uprave, mora u svezi s tom dužnošću primijeniti dužnu pozornost koja je potrebna za uredno obavljanje nadzora. Smjernica za obavljanje poslova nadzornog odbora jest - kao i za rad uprave - interes odnosno dobrobit sportskog dioničkog društva ${ }^{47}$ Nadzorni odbor mora donositi objektivne i neovisne odluke rukovodeći se u prvom redu dobrobiti s.d.d.-a. Članovi nadzornog odbora dužni su voditi računa o interesima sportskog dioničkog društva, a tek podredno o interesima njegovih dioničara koji mogu imati drugačije ciljeve i interese. Da bi ispunili svoju dužnost, članovi nadzornog odbora moraju uvijek postupati u dobroj vjeri (savjesno) te raspolagati informacijama koje su primjeren temelj za njihov rad. $^{48}$

S obzirom na to da ponekad nije jednostavno jasno odrediti što su interesi sportskog d.d.-a, nadzorni odbor (kao i uprava) kod obavljanja pojedinih zadaća ima pravo na poslovnu prosudbu. ${ }^{49}$ Posebice ima to pravo kada provodi tzv. preventivni nadzor. To će biti slučaj kada nadzorni odbor odlučuje o davanju suglasnosti upravi za neki posao. Međutim, kada nadzorni odbor naknadno kontrolira poslove koje je uprava već ranije poduzela (ex post) tada je pravo nadzornog odbora na poslovnu

46 Vidi toč. V. i VI. Kodeksa. Iz teksta (jezika) navedenih preporuka moglo bi se na prvi pogled zaključiti da nadzorni odbor daje upute upravi (,upravi treba davati jasne ciljeve“) te da nadzorni odbor sudjeluje u vođenju poslova (,surađivati s nadzornim odborom i postići sporazum glede provođenja strateških ciljeva“"), ali takav zaključak nije ispravan jer je Zakonodavac jasno propisao da uprava vodi poslove društva na vlastitu odgovornost (čl. 240. st. 1. ZTD-a).

47 Henze, H., o. c. u bilj. br. 1, str. 209. i dalje.

48 Usp. toč. IV. (preporuke nadzornom odboru) Kodeksa korporativnog upravljanja trgovačkim društvima u kojima Republika Hrvatska ima dionice ili udjele (Narodne novine 132/2017, 52/2018).

49 Vidi čl. 252. st. 1. reč. 2. ZTD-a. Ova odredba rezultat je višegodišnjih rasprava o pitanju odgovornosti uprave za poslovne odluke. U pravnoj znanosti pokušavaju se postaviti pretpostavke i granice poslovne prosudbe uprave $\mathrm{i}$ to upućivanjem na istoimeni institut američkog prava (,Business Judgment Rule“). Na tim temeljima njemački Savezni sud u presudi ARAG/Garmenbeck (Presuda BGH od 21. IV. 1997. - II ZR 175/95, BGHZ 135, str. 244-257; dostupna i na https://www.jurion.de/urteile/bgh/1997-0421/ii-zr-175 95/, pregledano 18. III. 2018.) gradi misao o prostoru za djelovanje uprave gdje u slučaju nepovoljnog ishoda (neuspjeha pothvata) ne dolazi automatski do odgovornosti uprave. U obrazloženju te presude navodi se da Upravi u svezi s poslovodstvom treba osigurati široki prostor za odlučivanje, bez kojega nije moguće poduzetnički djelovati. Odgovornost uprave dolazi u obzir samo onda kada se očito prekoračila granica odgovornog ponašanja tj. kada se ponašanje uprave više ne temelji na pažljivoj analizi svih odlučujućih činjenica odnosno onda kada se ta granica prekoračila na neodgovoran način ili je uprava na drugi način povrijedila dužnost da postupa s pozornošću urednog i savjesnog gospodarstvenika. Snaga uvjerljivosti presude ARAG/Garmenbeck dovela je do preoblikovanja njezinih ključnih dijelova u zakonski tekst i to u odredbu § 93 Abs. 1. S. 2. AktG koja glasi: „Nema povrede dužnosti ako član uprave kod poslovne prosudbe može razumno pretpostaviti da postupa za dobrobit društva a na temelju primjerene informacije. Detaljnije o tome Fleischer, H., Die „Business Judgment Rule“, o. c. u bilj. br. 1 , str. 685. i dalje. 
prosudbu znatno ograničeno odnosno potpuno isključeno. Nadzorni odbor se kod procjene postupanja uprave treba staviti u položaj uprave i to baš u vrijeme kada se donosila odluka o poduzimanju nekog posla. ${ }^{50}$

Intenzitet nadzora mora biti proporcionalan stupnju rizika povezanih $\mathrm{s}$ poduzimanjem konkretne mjere (tzv. stupnjevita nadzorna obveza). ${ }^{51}$ Odredbe o odgovornosti članova uprave kao i odredbe o odgovornosti za iskorištavanje utjecaja u društvu primjenjuju se analogijom i na članove nadzornog odbora. ${ }^{52}$ Tako se pravila o odgovornosti uprave, posebice ona o teretu dokazivanja, solidarnoj odgovornosti, oprostu duga, prijeboju i zastari te ona o naknadi štete primjenjuju mutatis mutandis na odgovornost članova nadzornog odbora. Dok nadzorni odbor podnosi tužbu društva za naknadu štete protiv sadašnjih ili bivših članova uprave, uprava je organ koji podnosi tužbu društva za naknadu štete protiv sadašnjih ili bivših članova Nadzornog odbora.

Nadzorni odbor provodi dvije vrste nadzora vođenja poslova: tekući i preventivni. Tekući nadzor obuhvaća analizu kvalitete rada uprave i rezultata koje je uprava ostvarila (rezultati društva), a koristi se osobito onda ako se pojavi sumnja u nepravilnosti u poslovanju društva. U tu svrhu mogu se pregledati i ispitati poslovne knjige i dokumentacija društva, nekretnine, roba, vozila, vrijednosni papiri itd. Obavljaju se redovna ispitivanja, a mogu se obaviti i tzv. ad hoc nadzori.

Iako se nadzor u društvu obavlja u pravilu naknadno, nakon što je neka mjera već poduzeta, uprava izvješćuje nadzorni odbor i o tome kako namjerava voditi poslove društva, tj. o poslovnim potezima koji tek slijede. Tako nadzorni odbor, nakon što dobije uvid u ono što uprava namjerava poduzeti, može donijeti odluku da će za poduzimanje neke mjere biti potrebna njihova suglasnost. Takva mu obaviještenost omogućuje obavljanje preventivnog nadzora. ${ }^{53}$ Težište utjecaja nadzornog odbora leži upravo u preventivnom nadzoru. Uprava mora izvješćivati nadzorni odbor o bitnim pitanjima za poslovanje i stanje društva. Nadzorni odbor ispunjenje svoje zadaće nadzora temelji na izvješćima uprave pa se mora pobrinuti da ta izvješća budu potpuna i istinita. Tako nadzorni odbor stječe vlastitu sliku o stanju sportskog dioničkog društva. Stupanj i opseg nadzora treba prosuđivati prema konkretnim

50 Vidi ključnu presudu njemačkog Saveznog suda (Bundesgerichtshof, u nastavku: BGH) BGHZ 135, 244 ,ARAG/Garmenbeck“.

51 O pitanju odgovornosti članova nadzornog odbora u usporednoj sudskoj praksi počelo se raspravljati tek u sedamdesetim i osamdesetim godinama prošlog stoljeća kada je došlo do znatnog porasta broja stečajeva dioničkih društava. Ujedno su time i članovi nadzornih odbora postali svjesni rizika obnašanje te funkcije. No vidljiv je trend utvrđivanja u praksi već oprobanih zajedničkih polazišta članova nadzornog odbora pa takav skup stavova doprinosi ostvarenju potrebne razine nadzora. Habersack, M., o. c. u bilj. br. $1, \S 111 \mathrm{Rdn}$. 44. Hoffmann-Becking ističe da treba razviti posebna "načela primjerenog nadzora" - skup smjernica za obavljanje zadaće nadzornog odbora. Hoffmann-Becking, M., Münchener Handbuch des Gesellschaftsrechts, o. c. u bilj. br. 1, § 29, Rdn. 34.

52 Vidi čl. 252, 272. i 272.a ZTD-a.

53 Hoffmann-Becking, M., Münchener Handbuch des Gesellschaftsrechts, o. c. u bilj. br. 1, § 29, Rdn. 35 . 
Dr. sc. Ratko Brnabić: Ovlasti nadzornog odbora u svezi s nadzorom uprave sportskog dioničkog... Zbornik radova Pravnog fakulteta u Splitu, god. 56, 2/2019, str. 377.- 399.

okolnostima. ${ }^{54}$ Stoga može biti korisno pa čak i nužno još jednom ispitati ranije odluke uprave da bi se stvorili prosudbeni standardi za buduće odluke. Naime, obveza izvješćivanja o odstupanjima od predviđanja omogućuje nadzornom odboru uvid $\mathrm{u}$ sustav upravljanja rizicima $\mathrm{u}$ poslovanju te $\mathrm{u}$ eventualne propuste $\mathrm{u}$ svezi s poslovnim planiranjem. To je važno utvrditi radi ocjene rada članova uprave, a posebice za ocjenu o tome postoji li važan razlog za opoziv imenovanja nekoga od njih. ${ }^{55}$ Zakonitost odluka uprave ispituje i utvrđuje nadzorni odbor što je i logično s obzirom na njegovu odgovornost za isticanje zahtjeva društva za naknadu štete protiv članova uprave..$^{56}$

\section{PRAVNA SREDSTVA ZA NADZOR VOĐENJA POSLOVA}

Nadzorni odbor raspolaže pravnim sredstvima kojima može i odlučujuće utjecati na ponašanje uprave. U prvom redu, nadzorni odbor ima konkretnu zadaću ispitivanja izvješća koja mu uprava podnosi po samom Zakonu. Uprava mora izvješćivati nadzorni odbor o poslovnoj politici i o drugim načelnim pitanjima budućeg vođenja

54 Ako se poslovi redovito i uspješno obavljaju, dovoljan je prateći nadzor nadzornog odbora. U kritičnim situacijama, naročito kad uprava zakaže, nadzorni odbor se mora aktivnije angažirati u nadzoru vođenja poslova. Gorenc, V. et al., o.c. u bilj br. 1, str. 525.

55 Navođenje u Zakonu pitanja o kojima uprava mora izvijestiti nadzorni odbor usmjereno je tome da se spriječi podnošenje paušalnih, pa i lakonskih izvješća koja se podnose samo da se zadovolji formalnost ne omogućujući nadzornom odboru pravi uvid u stanje stvari. Barbić, J., o. c. u bilj. br. 1, str. 719.-720.

56 Vidi čl. čl. 268. u svezi s čl. 252. st. 2. ZTD-a. Hodogram za postupanje nadzornog odbora u svezi s donošenjem odluke o podnošenju tužbe društva protiv člana uprave daje nam njemački Savezni sud u presudi Arag/Garmenbeck. U prvoj fazi ispitivanja nadzorni odbor provjerava postoji li pravni temelj za tužbu društva protiv članova uprave te jesu li ispunjene činjenične pretpostavke odgovornosti za naknadu štete. Nadzorni odbor utvrđuje je li član uprave povrijedio svoje dužnosti te da je zbog takvog ponašanja društvu nastala šteta. Treba uzeti u obzir da član uprave ne postupa suprotno svojim dužnostima u svezi s vođenjem poslova društva ako pri donošenju poduzetničke odluke smije na temelju primjerenih informacija razumno pretpostaviti da djeluje za dobrobit društva (pravilo poslovne prosudbe iz čl. 252. st. 1, reč. 2. ZTD-a). S druge strane, kod utvrđivanja činjeničnih pretpostavki odgovornosti za štetu nadzorni odbor nema pravo na poslovnu prosudbu. Nije dovoljno da postoji samo mogućnost povrede dužnosti već se mora utvrditi s dovoljnom sigurnošću da je do povrede dužnosti stvarno i došlo. Međutim, u već pokrenutoj parnici protiv člana uprave dovoljno je da društvo (koje u ovom slučaju zastupa nadzorni odbor) iznese postojanje okolnosti iz kojih proizlazi mogućnost povrede dužnosti uprave (premještaj tereta dokazivanja). Ako se i utvrdi povreda dužnosti kojom se uzrokovala šteta, još uvijek u prvoj fazi ispitivanja opravdanosti tužbe treba ispitati i procesne rizike, tj. utvrditi stupanj sigurnosti (izvjesnosti) uspjeha tužbe za naknadu štete protiv člana uprave te ispitati naplatnost tražbine prema članu uprave. Utvrdi li se s dovoljnom sigurnošću da postoje činjenične pretpostavke zahtjeva za naknadu štete te se može razumno pretpostaviti da će sud usvojiti tužbu a uz to da član uprave raspolaže privatnom imovinom podobnom za ovrhu (isplatu iznosa naknade štete), nadzorni odbor u drugoj fazi mora ispitati postoji li druga važna prepreka za isticanje zahtjeva a to je okolnost da "važni interesi društva govore u prilog prihvaćanju pretrpljene štete bez naknade", a te okolnosti "nadmašuju ili su barem jednake snage (značaja) i uvjerljivosti kao i stav da treba ustati s tužbom". Tu je opet riječ o poslovnoj prosudbi nadzornog odbora. $\mathrm{S}$ tim u svezi njemački Savezni sud ističe da su elementi od značaja za odluku "negativni učinci na poslovanje tvrtke i javni ugled, ometanje rada uprave i narušavanje radne atmosfere" koji mogu nastupiti u slučaju podizanja tužbe protiv člana uprave". S druge strane, kriteriji kao što su "zaštita zaslužnog člana uprave" ili "opseg negativnih socijalnih posljedica presude za člana uprave i njegovu obitelj” treba uzeti u obzir samo u iznimnim slučajevima. Vidi BGHZ („Entscheidungen des Bundesgerichtshofes in Zivilsachen“) 135, str. 254. i dalje. Cahn smatra da kod te procjene nije potrebno utvrditi da isticanje tužbe predstavlja ponašanje nadzornog odbora suprotno interesima društva. Cahn, A., o. c. u bilj. br. 1, str. 1295. 
poslova te odstupanjima od ranijih predviđanja s navođenjem razloga za to, o rentabilnosti poslovanja društva a napose rentabilnosti upotrebe vlastitoga kapitala, o tijeku poslova, napose prihoda i stanja društva te o poslovima koji bi mogli biti od velikog značaja za rentabilnost poslovanja i za likvidnost društva. ${ }^{57}$ Nadzorni odbor podnosi glavnoj skupštini pisano izvješće o obavljenom nadzoru. U izvješću dužan je posebno navesti djeluje li društvo u skladu sa zakonom i aktima društva te odlukama glavne skupštine, jesu li godišnja financijska izvješća napravljena u skladu sa stanjem u poslovnim knjigama društva i pokazuju li ispravno imovinsko i poslovno stanje društva te stav koji ima o prijedlogu uprave glede upotrebe dobiti i pokrića gubitka u društvu. ${ }^{58}$ Nadzorni odbor može u svako doba tražiti od uprave da ga izvijesti o pitanjima koja su povezana s poslovanjem društva i koja značajnije utječu na položaj društva ili se razumno može očekivati da bi na to mogla utjecati. On može zahtijevati podnošenje izvješća o prilikama društva, pravnim i poslovnim odnosima s povezanim društvima, a uprava je dužna odboru podnijeti zahtijevano izvješće. ${ }^{59}$

Nadzorni odbor može pregledavati i ispitivati poslovne knjige i dokumentaciju društva, blagajnu, vrijednosne papire i druge stvari te općenito zahtijevati od uprave da ga izvješćuje i o drugim pitanjima koja su značajna za poslovanje i stanje društva. U tu svrhu odbor može koristiti pojedine svoje članove ili stručnjake. Nadzorni odbor daje nalog revizoru za ispitivanje godišnjih financijskih izvješća društva i koncerna. $^{60}$

Nadzorni odbor ima ovlasti i u svezi s godišnjim financijskim izvješćima s.d.d.-a. Uprava je dužna podnijeti nadzornom odboru godišnja financijska izvješća i izvješće o stanju društva (ako ga je društvo dužno izraditi) bez odgađanja od kada ih sastavi. Istodobno s podnošenjem godišnjih financijskih izvješća, uprava je dužna nadzornom odboru predočiti i prijedlog odluke o upotrebi dobiti koji želi predložiti glavnoj skupštini za donošenje (podjelu dioničarima, unos u rezerve, zadržanu dobit). Nadzorni odbor mora ispitati godišnja financijska izvješća, izvješće o stanju društva i prijedlog odluke o upotrebi dobiti. Ako godišnja financijska izvješća ispituje revizor, dužan je sudjelovati u radu sjednice nadzornog odbora i njegovih povjerenstava na kojima se ona ispituju, dati svoje izvješće uz objašnjenja koja se od njega traže. Nadzorni odbor mora u pisanom obliku izvijestiti glavnu skupštinu o rezultatima ispitivanja te mora navesti na koji je način i u kojem opsegu tijekom poslovne godine ispitao vođenje poslova društva. U izvješću se mora navesti ima li nadzorni, odnosno upravni odbor primjedaba na podnesena mu izvješća i daje li suglasnost na godišnja financijska izvješća koja mu je podnijela uprava. Nadzorni odbor dužan je svoje izvješće dostaviti upravi u roku od mjesec dana nakon što su

57 Vidi čl. 250. st. 1. ZTD-a.

58 Vidi čl. 263. st. 3. ZTD-a.

59 Zahtjev da uprava podnese izvješće može postaviti svaki član nadzornog odbora, a svaki član ima individualno pravo dobiti izvješće na uvid. Time se svakom članu nadzornog odbora nameće obveza da postupa s dužnom pozornošću te se ne može osloboditi odgovornosti prigovorom da je izvješća trebao zatražiti predsjednik nadzornog odbora ili nadzorni odbor na sjednici.

${ }^{60}$ Vidi čl. 263. st. 2. ZTD-a. 
mu podnesena sva izvješća koja treba ispitati ili najkasnije u dodatnom roku od mjesec dana koji mu daje uprava. Dade li nadzorni odbor suglasnost na godišnja financijska izvješća, time su ih utvrdili uprava i nadzorni odbor. Protekom tog roka a da se nadzorni odbor nije očitovao, smatra se da nije dana suglasnost na izvješća uprave. U tom slučaju glavna skupština utvrđuje godišnja financijska izvješća. ${ }^{61}$

Ne smije se zaboraviti da nadzorni odbor također intenzivno kontrolira vođenje poslova društva putem ovlasti da imenuje i opoziva članova uprave. ${ }^{62}$ Odluka o imenovanju člana uprave kojega je imenovao nadzorni odbor može se opozvati samo zbog važnog razloga. Propisivanjem važnog razloga za opoziv imenovanja članova uprave sprečavaju se samovolja glede opoziva njihova imenovanja i neizvjesnost o njihovoj sudbini u društvu te im se osigurava nezavisnost u djelovanju, što odgovara njihovu položaju da vode poslove društva na vlastitu odgovornost. Ne može stoga svaka pogreška u poslovanju odmah rezultirati opozivom odluke o imenovanju onoga člana uprave koji ju je učinio. Kad bi to bilo moguće, to bi štetno utjecalo na kreativnost članova uprave koji bi izbjegavali poduzeti bilo kakav poslovni potez u kojemu ima imalo rizičnosti, čime bi se zakočio razvitak struke. ${ }^{63}$ Važan razlog za opoziv imenovanja člana uprave može biti i nepridržavanje internih ograničenja određenih statutom društva, odlukama nadzornog odbora i glavne skupštine društva. Za to je npr. dovoljno da nadzorni odbor donese odluku kojom zahtijeva da direktor može određene poslove obavljati samo uz suglasnost tog odbora pa on to učini bez dobivene suglasnosti. ${ }^{64}$ Nadzorni odbor zastupa društvo prema članovima uprave što će posebice doći do izražaja kod podizanja tužbe društva protiv članova uprave (bivših i/ili sadašnjih).

Nadzorni odbor može sazvati skupštinu sportskog dioničkog društva, a to mora učiniti radi dobrobiti društva. ${ }^{65}$ Tako nadzorni odbor može potaknuti donošenje odluke koja spada u nadležnost glavne skupštine. Spomenutim pravom nadzorni odbori rijetko se u praksi koriste jer će uprava koja je u prijeporu s nadzornim odborom najčešće i sama sazvati skupštinu da bi otklonila svoju odgovornost. Dobrobit društva zahtijeva sazivanje skupštine npr. kada je zbog ponašanja nekog člana uprave potrebno da glavna skupština donese odluku o uskrati povjerenja članu uprave što onda predstavlja važan razlog za njegov opoziv. Uprava vodi poslove pa ona odlučuje hoće li se neko pitanje u svezi s poslovodstvom postaviti pred skupštinom društva. U takvim slučajevima nadzorni odbor može donijeti odluku da je za tu mjeru potrebna njihova suglasnost i tako spriječiti upravu da je poduzme ili

61 Vidi čl. 300.a - 300.e ZTD-a.

62 Vidi čl. 244. ZTD-a.

63 Mjerila za opoziv odluke o imenovanju člana nadzornog odbora čine članove tog organa neovisnijima o nadzornom odboru nego što bi bili u slučaju da ih taj odbor može opozvati po slobodnoj ocjeni i bez ikakvih ograničenja. Time su stavljeni u položaj da se bez straha mogu oduprijeti eventualnim zahtjevima nadzornog odbora da u vođenju poslova društva poduzmu radnje s kojima se ne slažu ili koje nemaju opravdanja. Barbić, J., Pravo društava, o. c. u bilj. br. 1, str. 765.

64 Ibid., str. 766.

65 Vidi čl. 263. st. 4. ZTD-a. 
može za glavnu skupštinu pripremiti odluku o nepovjerenju članovima uprave što je pretpostavka za njihov opoziv.

Nadzorni odbor utječe na rad uprave putem izmjena poslovnika o radu uprave, a posebice izmjenom odredbe tog poslovnika o podjeli poslova u upravi društva. ${ }^{66}$

Nadalje, s obzirom na to da se statutom ili odlukom nadzornog odbora može odrediti da se određene vrste poslova mogu obavljati samo uz suglasnost nadzornog odbora, odluka o davanju suglasnosti predstavlja još jedno sredstvo kojim raspolaže taj organ o čemu će biti više riječi poslije u radu.

Kod donošenja odluka nadzorni odbor prvenstveno se oslanja na informacije koje mu podnosi uprava putem pisanih izvješća ili usmenim putem. Pozornost urednog člana nadzornog odbora nalaže da se od uprave traže dopunska izvješća ili da nadzorni odbor i sam utvrđuje činjenice ako su izvješća uprave nejasna, nepotpuna ili očito netočna. Naravno, nadzorni odbor se kod odlučivanja neće ograničiti samo na izvješća i ostale informacije koje im podnosi uprava ili na stavove uprave, već će koristiti znanje i iskustvo pojedinih članova nadzornog odbora. ${ }^{67}$

Zakon ne sadrži upute o tome koje je informacije potrebno prikupiti za donošenje meritorne odluke. Za učinkovito i kvalitetno ostvarivanje funkcije nadzora nad poslovanjem i funkcije donošenja upravljačkih i usmjeravajućih odluka, mora se poći od pretpostavke da je fond znanja, informacija i upravljačkih vještina kojima raspolaže nadzorni odbor barem ravnopravan onome kojim raspolaže uprava. $\mathrm{U}$ suprotnom slučaju, uprava bi mogla lako manipulirati činjenicama i procesom korporativnog odlučivanja, npr. tako da navodi na pogrešne procjene i zaključke, ili tako da predlaže i provodi nisko ambiciozne ciljeve poslovnih politika društva. ${ }^{68}$ Nadzorni odbor mora, prema vlastitoj prosudbi, odrediti opseg i sadržaj informacija potrebnih za predmetnu odluku. Nadzorni odbor mora biti primjereno informiran o svim važnim okolnostima u svezi s takvim pravnim poslovima da bi mogao procijeniti sve rizike. ${ }^{69}$ Uoči li uprava da nadzorni odbor zloupotrebljava svoje ovlasti u svezi s informiranjem ili ako postoji sumnja da je riječ o kaznenom djelu nadzornog odbora, uprava može nadzornom odboru uskratiti pristup informacijama ili dokumentima. U slučaju dvojbe, nadzorni odbor u svom zahtjevu upravi mora navesti razlog zbog kojeg im je potrebna neka informacija, a posebice onda kad se od uprave zahtijeva podatak koji nije u izravnoj vezi sa zadaćom nadzora vođenja poslova. Uprava ne mora nadzornom odboru pružati informacije npr. o osobnim stvarima člana uprave ili zaposlenika sportskog dioničkog društva. Uprava ne može odbiti pružiti informacije nadzornom odboru pozivajući se na javni interes. Članovi nadzornog odbora dužni su čuvati poslovnu tajnu jednako kao i članovi uprave.

66 Spindler, G., o. c. u bilj. br. 1, § 77 Rdn. 48.

67 Brandi, A., o. c. u bilj. br. 1, str. 173. i dalje.

68 Još gora posljedica neravnoteže upravljačkih kompetencija zna biti ta, da se nadzorni odbor osjeća nesigurnim ili čak inferiornim u odnosu na upravu i stručne službe poduzeća, pa svoju dužnost nadzora pretvori u eksperimentiranje moći što nužno dovodi do ozračja nepovjerenja, pretjerano oprezne $\mathrm{i}$ neiskrene komunikacije - najčešće na štetu poslovanja. Barbić J. et al., o. c. u bilj. br. 1, str. 27.

69 Habersack, M., o. c. u bilj. br. 1,§ 111, Rdn. 127. 
Nadzorni odbor ostvaruje utjecaj na upravu svojim odlukama, ali i iznošenjem stavova, mišljenja, primjedbi, postavljanjem upita kako u pisanoj formi tako i usmeno. Tako nadzorni odbor djeluje putem svojih odluka (odluka nadzornog odbora u užem smislu riječi, npr. o imenovanju/opozivu imenovanja članova uprave društva, o osnivanju posebnih komisija i sl., o odobrenju zajma članu uprave/ nadzornog odbora), suglasnosti (i ovdje je zapravo riječ o odlukama ali o onima kojima je u pravilu prethodio zahtjev uprave, npr. da im se odobri poduzimanje nekog posla ili da im nadzorni odbor dade suglasnost na izvješće o poslovanju društva za prvo polugodište poslovne godine, suglasnost na rebalans proizvodnog, prodajnog i financijskog plana društva za tekuću poslovnu godinu, suglasnost za osnivanje d.o.o.-a kao društva kćerke, suglasnost na poslovni plan društva za sljedeću poslovnu godinu, suglasnost za sklapanje kupoprodajnog ugovora veće vrijednosti, suglasnost na financijska i poslovna izvješća uprave itd.), stavova (npr. kod izvješća nadzornog odbora o obavljenom nadzoru nad poslovanjem s.d.d.-a) i mišljenja (kada nadzorni odbor djeluje kao savjetodavno tijelo). Nadzorni odbor može zatražiti od uprave održavanje dodatnih (formalnih) konzultacija.

Donošenjem stavova, mišljenja, napomena na sjednicama, nadzorni odbor djeluje i kao savjetodavno tijelo uprave. Nadzorni odbor može dati mišljenje o svim pitanjima iz djelokruga vođenja poslova, ali ta očitovanja za upravu nisu pravno obvezujuća. Najčešće se mišljenje daje u svezi s poslovnim planiranjem (financijska, investicijska i kadrovska pitanja).

Funkcije savjetovanja i nadzora povezane su te ih se ne može uvijek jasno razlikovati. Naime, nadzorni odbor uz zadaću praćenja zakonitosti i pravilnosti odluka iz područja vođenja poslova mora djelovati i šire pa njegovo savjetodavno djelovanje predstavlja pojavni oblik nadzora poslovanja. ${ }^{70}$ Mudra uprava zatražit će mišljenje i preporuku nadzornog odbora i kod donošenja svih odluka koje se odnose na poslovne pothvate koji nose velike rizike za društvo, čak i onda kada za tu odluku ili mjeru poslovne politike nije dužna zatražiti suglasnost nadzornog odbora i kada nema nikakve sumnje o zakonitosti takvih odluka. Tada nadzorni odbor treba prema vlastitoj savjesti prosuditi o ispravnosti, a ne o legitimnosti dotične odluke ili (na) mjere poslovne politike. ${ }^{71}$

Nadzorni odbor preko svojih članova ili vanjskih stručnjaka može ispitati i pregledati poslovne knjige i dokumentaciju društva kao i imovinu, odnosno blagajnu društva, vrijednosne papire i druge stvari. ${ }^{72}$ Tim pravom će se spomenuti organ koristiti ako je zbog što kvalitetnijeg obavljanja nadzora potrebno pribaviti dodatne $\mathrm{i} / \mathrm{ili}$ potpunije informacije.

Nadzorni odbor posebno mora nadzirati da uprava ne poduzme neku od nedopuštenih radnji, a to će biti posebice onda kada članovi uprave vrate dioničarima ono što su uložili u društvo, isplate dioničarima kamate ili dividendu, kada upišu, steknu, uzmu u zalog ili povuku vlastite dionice društva ili nekoga drugoga društva,

70 Henze, H., o. c. u bilj. br. 1, str. 165. i dalje.

71 Barbić J. et al., o. c. u bilj. br. 1, str. 31.

72 Vidi čl. 263. st. 2. ZTD-a. 
izdaju dionice prije nego što se za njih u cjelini uplati iznos za koji su izdane, razdijele imovinu društva, obave plaćanja nakon što nastupi nesposobnost društva za plaćanje, odnosno nakon što dođe do prezaduženosti društva, dadu naknadu članovima nadzornog odbora, dadu kredit i za slučaj kada kod uvjetnog povećanja kapitala izdaju dionice suprotno svrsi ili prije nego što se one u cjelini uplate. ${ }^{73}$

Nadzorni odbor koristit će usluge stručnjaka samo za konkretnu zadaću nadzora i samo za razdoblje koje je potrebno za obavljanje te zadaće. ${ }^{74}$ Ako nadzorni odbor koristi usluge vanjskih stručnjaka, tada taj organ kod sklapanja takvih ugovora zastupa društvo pri čemu ono stječe prava i obveze.$^{75}$ Mora postojati i konkretan razlog za davanje naloga stručnjaku; to će osobito biti onda kada su se informacije koje je dostavila uprava od samog početka pokazale nedostatnima ili neprimjerenima (osobito u slučaju sumnje u pogreške članova uprave). Iako nadzorni odbor može provoditi nenajavljene povremene provjere rada uprave pa u tu svrhu koristiti i (vanjske) stručnjake, zbog odnosa povjerenja između tih dvaju organa preporuka je da se tako postupi samo ako za to postoji konkretan povod. Oni mogu ispitati i pregledati svu imovinu društva, uključujući i sve stvari koje spadaju u tu imovinu, a za tu svrhu dostupna im je i cjelokupna baza podataka društva kako u papirnatom tako i u elektroničkom obliku. ${ }^{76}$ Nadzorni odbor kod odabira stručnjaka mora postupati s pozornošću urednog i savjesnog gospodarstvenika i odgovara za taj izbor (culpa in eligendo). Stručnjaku postaju dostupne povjerljive informacije te je uvijek dužan na tajnost, a najčešće ta dužnost proizlazi već $i$ iz pravila njegove struke (profesionalna tajna).

Nadzorni odbor može osnovati i povjerenstva (komisije) radi pripreme odluka koje donosi i nadzora njihova provođenja. Povjerenstva ne mogu odlučivati o pitanjima iz nadležnosti nadzornog odbora. Povjerenstva su dužna o svom radu redovito izvješćivati nadzorni odbor. ${ }^{77}$ Veća dionička društva najčešće imaju povjerenstvo (odbor) za vrednovanje rada i nagrađivanje, za društvenu odgovornost poslovanja, za strateško planiranje, za žalbe i pritužbe u svezi s organizacijskim načelima i propisima, za kadrovsku politiku i promaknuća itd. Kod sportskih dioničkih društava trebalo bi, zbog posebitosti sportske djelatnosti i pripadajućih poslova, formirati odbor za sportska pitanja koji bi pomagao u radu nadzornog odbora, a to posebice onda kada nijedan član nadzornog odbora ne posjeduje odgovarajuća stručna znanja ni iskustvo iz područja sporta. Ova tijela pomažu nadzornom odboru da stalno ima u vidu rendgensku sliku tekućih zbivanja i procesa, a ne samo kratkoročne činjenice i financijske pokazatelje ekonomike poslovanja no,

73 Vidi čl. 252. st. 3. ZTD-a. i dalje.

74 Koch, J., o. c. u bilj. br. 1,§ 111, Rdn. 12. Usp. Hoffmann-Becking, M., o. c. u bilj. br. 1, str. 136.

75 Nadzorni odbor zastupa društvo i kod sklapanja pomoćnih poslova koji služe nadzornom odboru za ispunjavanje njegovih zakonskih obveza, a taj organ bi za stručne (savjetodavne) usluge prvenstveno trebao koristiti interne ljudske resurse društva (stručnjake koji su zaposlenici društva). Hoffmann-Becking, M., o. c. u bilj. br. 1, str. 140 .

76 Usp. Habersack, M., o. c. u bilj. br. 1,§ 111, Rdn. 74.

77 Vidi čl. 264. st. 3. ZTD-a. 
s druge strane, ona nemaju nikakve ovlasti u odnosu na upravu društva, osim da u segmentu svog rada iznose mišljenja i prijedloge odluka iz nadležnosti nadzornog odbora. Mogu se sastojati od članova nadzornog odbora, ali i od stručnjaka koji nisu članovi tog organa. ${ }^{78}$

\section{POSLOVI UPRAVE ZA KOJE JE POTREBNA SUGLASNOST NADZORNOG ODBORA}

Uprava vodi poslove društva na vlastitu odgovornost dok nadzorni odbor ima primarnu dužnost nadzora nad vođenjem poslova. Nadzorni odbor nije ovlašten na vođenje poslova društva iako raspolaže pravnim sredstvima kojima može utjecati na upravu i njezin rad. Međutim, statutom, poslovnikom o radu uprave ili odlukom nadzornog odbora može se propisati da je za obavljanje određenih poslova koji spadaju u nadležnost uprave potrebna (prethodna) suglasnost nadzornog odbora. Valja posebno naglasiti da nadzornom odboru pripada neotuđivo pravo da bez obzira na statut donese odluku kojom utvrđuje da je za neku mjeru uprave potrebna suglasnost nadzornog odbora iako će se on tim pravom rijetko koristiti. Statutom se ne može isključiti niti ograničiti pravo nadzornog odbora na utvrđivanje kruga poslova uprave za koje je potrebna suglasnost nadzornog odbora. ${ }^{79}$ Problem u praksi mogao bi nastati ako je u statutu naveden samo dio poslova za koje je potrebna suglasnost, a ostatak je naveden u poslovniku o radu uprave/nadzornog odbora ili u posebnoj odluci nadzornog odbora. Lista tih poslova češće se može naći u poslovnicima nego u statutima tih društava i to ponajprije iz praktičnih razloga: jednostavnije je izmijeniti poslovnik o radu nadzornog odbora ili uprave nego statut društva. Upravo zbog navedenog preporučuje se da nadzorni odbori kontroliraju i prema potrebi ažuriraju listu takvih poslova ${ }^{80} \mathrm{~S}$ obzirom na to da se poslovnici o radu kao i pojedinačne odluke nadzornog odbora u pravilu ne objavljuju, ponekad neće biti jednostavno utvrditi za koje će sve poslove uprave biti potrebna suglasnost nadzornog odbora.

Iako nadzorni odbor daje suglasnost, time taj organ ne prisvaja ovlasti uprave, jer sam nije ovlašten inicirati niti poduzimati predmetne poslove, a posebice nije ovlašten dati upravi obvezujuću uputu za postupanje u konkretnom slučaju. Nadzorni odbor ili glavna skupština mogu dati suglasnost upravi za obavljanje određenih poslova, ali ta suglasnost ne može zamijeniti radnju vođenja poslova društva koju bi uprava trebala obaviti na temelju te suglasnosti. Da suglasnost nadzornog odbora nije obvezujuća uputa za postupanje, postaje vidljivo npr. u slučaju kada je uprava dobila takvu suglasnost. Bez obzira na to što je nadzorni odbor dao suglasnost, uprava može odustati od posla ako s motrišta uprave taj posao više ne odgovara

\footnotetext{
78 Usp. Barbić, J. et al., o. c. u bilj. br. 1, str. 25.

79 Koch, J., o. c. u bilj. br. 1, § 111, Rdn. 38.

80 Pod pretpostavkom da je društvo u svojim autonomnim aktima navelo te poslove.
} 
interesima društva. ${ }^{81}$ Inicijativa za poduzimanje nekog posla i dalje pripada samo upravi, ona i dalje odgovara za vođenje poslova, a suglasnost nadzornog odbora za neki posao ne oslobađa je odgovornosti. ${ }^{82}$ Uskratom suglasnosti ne sprečava se upravu da poduzme taj posao, ali time nastaje važan razlog za opoziv imenovanja članova uprave te za tužbu za naknadu štete protiv član(ov)a uprave.

Kada je riječ o krugu poslova čije se poduzimanje uvjetuje pribavljanjem suglasnosti nadzornog odbora, našim ZTD-om nije propisano koji poslovi tu spadaju već se, kako je poviše navedeno, to pitanje može urediti statutom, poslovnikom o radu uprave, ali i odlukom nadzornog odbora. S obzirom na to da uprava vodi poslove društva na vlastitu odgovornost, općenito vrijedi da tu ne spadaju poslovi redovitog poslovanja, već se suglasnost može zahtijevati samo za poslove većeg opsega ili rizične poslove. Važno je u aktima društva precizno opisati poslove za čije je obavljanje potrebna suglasnost. Nije dostatno u statutu društva navesti da je suglasnost nadzornog odbora potrebna za sve izvanredne poslove, poslove od velikog značaja za društvo ili rizične poslove. ${ }^{83}$ Suglasnost je potrebna za temeljne, važne odluke o korporativnoj strategiji i za važne investicijske odluke kojima se znatno utječe na sposobnost društva da ostvaruje dobit ${ }^{84}$ Nadzorni odbor ne postupa suprotno svojim dužnostima samo zato što nije donio ili naknadno proširio listu poslova uprave za koje je potrebna ta suglasnost. ${ }^{85}$ Stoga u ovom trenutku za naše pravo ne bi bilo dobro rješenje da se, primjerice, Zakonom o sportu uvede dužnost sportskih dioničkih društava da statutom utvrde listu poslova uprave za koje je potrebna prethodna suglasnost nadzornog odbora. Takvom odredbom navelo bi se spomenuta društva da unesu takve odredbe u svoje statute iako za to nema stvarne potrebe. Naime, nadzorni odbor u svezi sa svojim dužnostima mora nadzirati vođenje poslova bez obzira na to je li statutom ili poslovnikom donesen popis poslova za čije je poduzimanje potrebna suglasnost. Stoga nadzorni odbor odgovara samo onda kada se pokaže da je u svezi s konkretnim poslom koji se pokazao štetnim za s.d.d. morao reagirati i spriječiti da ga uprava poduzme.

Najčešce se suglasnost nadzornog odbora traži za sljedeće poslove/mjere: utvrđivanje smjernica i ciljeva poslovne politike i strategije društva, utvrđivanje financijskog plana i godišnjeg proračuna, donošenje i promjene računovodstvenih politika, davanje suglasnosti na godišnja financijska izvješća, stjecanje i prodaja dionica/udjela u drugim trgovačkim društvima, prijenos pogona, kupnja, otuđenje i opterećenje nekretnina, ulaganja koje pojedinačno prelaze određeni iznos, preuzimanje novih kreditnih obveza izvan okvira financijskog plana, kupnja i

81 Habersack, M., o. c. u bilj. br. 1, § 111 Rdn. 128. Također niti suglasnost glavne skupštine ne znači da je taj organ preuzeo vođenje poslova jer opet zadnju riječ ima uprava.

82 Vidi čl. 252. st. 4. ZTD-a.

83 Usp. Fleischer, H., Gestaltungsgrenzen für Zustimmungsvorbehalte, o. c. u bilj. br. 1, str. 835.

84 I donošenje poslovnog plana jest mjera za koju se može propisati obveza dobivanja suglasnosti nadzornog odbora. To vrijedi i za višegodišnje (strateško) planiranje. Fonk, H. J., o. c. u bilj. br. 1, str. 850.

85 Međutim, ovisno o stanju društva i ponašanju uprave, njegova procjena može postati obveza; primjerice, ako nadzorni odbor može spriječiti nezakonitu mjeru upravljanja od strane uprave ad hoc odobrenjem rezervacije suglasnosti. Götz, H., o. c. u bilj. br. 1, str. 639. 
otuđenje licencije, sklapanje dugoročnih ugovora koji pojedinačno prelaze određeni iznos, značajna promjena programa proizvoda i usluga društva, učlanjenja u različita udruženja, stupanje u gospodarsko interesno udruženje, izbor i smjena članova povjerenstava a koja povjerenstva osniva/ukida uprava itd. Kada je riječ o sportskim dioničkim društvima, suglasnost nadzornog odbora zahtijeva se i kod odluke o izboru trenera prve momčadi, sportskog direktora i voditelja omladinske škole te za raskid, otkaz i obnovu pravnih poslova sklopljenih s igračima.

Bez obzira na to jesu li statutom ili poslovnikom utvrđeni poslovi za koje je potrebna prethodna suglasnost nadzornog odbora, taj organ svojom odlukom uvijek može i proširiti i suziti taj krug poslova. Pri utvrđivanju takvih poslova, nadzorni odbor mora uzeti u obzir konkretne okolnosti tog društva, ali uvijek imajući u vidu da nadzorni odbor nije ovlašten na poslovodstvo. Nadzorni odbor mora periodički provjeravati odgovara li trenutni popis tih poslova i dalje konkretnim okolnostima tog društva odnosno predmetu i opsegu poduzetničkog pothvata. Ta odluka nadzornog odbora ne spada u poslovnu prosudbu jer je tu riječ samo o određivanju kruga poslova kod kojih je potrebna suglasnost, a nije riječ o nekom konkretnom poslu. Nije dopustivo ponašanje nadzornog odbora ako širokim popisom takvih poslova ograniči upravu do te mjere da ona zapravo ne može ništa poduzeti bez njegove suglasnosti. Suglasnost se može odnositi samo na poslove kojima se znatno mijenja imovinski položaj društva, a ne na redovite poslove društva.

Uoči li nadzorni odbor da bi neka mjera uprave mogla predstavljati povredu njegovih dužnosti, može donijeti odluku da je za takvu mjeru potrebna suglasnost nadzornog odbora te $\mathrm{u}$ istom aktu i odluku kojom upravi odbija dati suglasnost za takav posao. S motrišta podjele poslova između organa društva nije dopustivo da nadzorni odbor daje obvezujuće upute upravi o tome kako mora postupiti da bi dobila njegovu suglasnost. Nije uvijek jednostavno razgraničiti slučajeve kada je opravdan zahtjev da se za neki posao prethodno pribavi suglasnost nadzornog odbora od slučaja kada nadzorni odbor zloupotrebljava svoje ovlasti u svezi s davanjem te suglasnosti.

Uprava je dužna suglasnost zatražiti prije poduzimanja konkretnog posla (prethodna suglasnost). No ako je riječ o poslovima koji ne trpe odgodu ili o poslovima za koje uprava može razumno pretpostaviti da će se nadzorni odbor složiti da se poduzmu, suglasnost bi mogla zatražiti i naknadno. Uprava mora uputiti pisani zahtjev nadzornom odboru u kojem će navesti opravdani razlog za takvo postupanje, a prethodno o tome treba obavijestiti predsjednika nadzornog odbora $\mathrm{i}$ zatražiti njegovo mišljenje. ${ }^{86}$

Ako je sam nadzorni odbor svojom odlukom uveo dužnost uprave da pribavi suglasnost za neki posao, tada taj organ može unaprijed dati i svoju suglasnost za konkretan posao. Drugačije vrijedi ako je statutom društva predviđeno da je za

86 Usp. Barbić, J. et al., o. c. u bilj. br. 1, str. 870. Uprava je dužna barem zatražiti prethodno odobrenje od predsjednika nadzornog odbora ako i nema vremena čekati tu odluku nadzornog odbora. Posao mora biti takav da bi uskraćivanje suglasnosti bilo suprotno dužnoj pozornosti koja se očekuje od članova nadzornog odbora. 
Dr. sc. Ratko Brnabić: Ovlasti nadzornog odbora u svezi s nadzorom uprave sportskog dioničkog... Zbornik radova Pravnog fakulteta u Splitu, god. 56, 2/2019, str. 377.- 399.

neki posao potrebna prethodna suglasnost. U tom slučaju nadzorni odbor ne može unaprijed dati suglasnost. ${ }^{87}$

Za štetu koja društvu nastane iz poslova za koje je upravi potrebna prethodna suglasnost nadzornog odbora (ako su poslovi poduzeti na temelju te suglasnosti te ako su za štetu odgovorni i članovi nadzornog odbora), uz članove uprave, i članovi nadzornog odbora solidarno odgovaraju društvu.

Ako je nadzorni odbor odbio dati suglasnost upravi za konkretan posao, uprava je može zatražiti od glavne skupštine ${ }^{88} \mathrm{O}$ tome glavna skupština odlučuje kvalificiranom većinom (3/4) glasova i samo kada se ta pretpostavka ispunila više nije potrebna suglasnost nadzornog odbora. ${ }^{89}$

\section{ZAKLJUČAK}

Rasprava o položaju i ovlastima nadzornih odbora dioničkih društava te o odnosu uprave i drugih organa glede vođenja poslova dioničkih društava prenosi se i na polje sportskog prava pa tako dobiva dodatna obilježja iz te pravne grane. Prema Zakonu o sportu koji je lex specialis u odnosu na Zakon o trgovačkim društvima, sportska dionička društva zasad mogu biti ustrojena samo na dualistički način, a tim propisom dodatno je sužen krug osoba koje mogu postati članovi nadzornog odbora. Uz to, sportska dionička društva obavljaju i djelatnosti koje nisu uobičajene za ostala dionička društva, a to su ponajprije djelatnost sudjelovanja u sportskim natjecanjima te organiziranje i vođenje tih natjecanja. Spomenuta društva za cilj imaju i ostvarenje sportskih rezultata, a ne samo ostvarenje dobiti, pa njihove uprave i nadzorni odbori, svatko u okviru svojih ovlasti (vođenje poslova odnosno nadzor vođenja poslova), donose i odluke koje spadaju u sportsku domenu poslovanja sportskog dioničkog društva.

Kada je riječ o ovlastima nadzornog odbora sportskih dioničkih društava, nema dvojbe da je ta materija uređena Zakonom o trgovačkim društvima a ne Zakonom o sportu pa nam taj propis daje odgovore i na pitanja koja često postavlja šira

87 Izuzetak je jedino slučaj kada je statutom izričito dano opće odobrenje da se suglasnost može zatražiti i naknadno. Detaljnije o tome vidi Habersack, M., o. c. u bilj. br. 1, § 111 Rdn. 126.

${ }_{88}$ Kod naročito važnih odluka - primjerice o zaključivanju strateških saveza, akvizicija, prodaji dionica ili kod velikih promjena proizvodnog programa, zatvaranja pogona ili outsourcinga - uprava i nadzorni odbor mogu o tome tražiti izjašnjavanje glavne skupštine društva.

89 Vidi čl. 263. st. 5. ZTD-a. Zahtjev za tročetvrtinskom većinom ne može se otežati niti olakšati statutom niti se može zaobići korištenjem drugih pravnih sredstava u svezi s odlučivanjem. Primjerice, uprava bi mogla, pozivanjem na čl. 275. st. 3. ZTD-a, zatražiti od glavne skupštine da se izjasni o nekoj mjeri koja spada u vođenje poslova društva za koju odluku je dovoljna obična većina glasova ako statutom nije drugačije određeno. To bi teoretski moglo biti u slučaju kada je nadzorni odbor donio ad hoc odluku da je za neki posao potrebna njegova suglasnost a da to nije uneseno u statut društva. Međutim takva većina neće biti dostatna kad je riječ o poslu za čije je poduzimanje potrebna suglasnost nadzornog odbora a nadzorni odbor je odbio dati tu suglasnost ili je uprava još nije niti zatražila. Stoga, za slučaj kada nadzorni odbor nije dao suglasnost jer mu uprava nije niti podnijela takav zahtjev, stavljanjem pitanja pred glavnu skupštinu uprava ne može izbjeći uvjet da se o tome odlučuje kvalificiranom većinom. Usp. Koch, J., o. c. u bilj. br. 1, § 119, Rdn. 14. 
sportska javnost. Najčešća pitanje jest trebaju li članovi organa sportskih dioničkih društava imati posebna stručna znanja i vještine da bi ispunili ne samo gospodarske nego i sportske ciljeve te pitanje do koje mjere (ako uopće) nadzorni odbor smije „sudjelovati“ u vođenju poslova sportskog dioničkog društva.

Jasno se pokazalo da je tu i dalje riječ o dioničkim društvima iz Zakona o trgovačkim društvima, usprkos nekim posebnostima koje proizlaze iz Zakona o sportu te iz same prirode sportskog natjecanja. Stoga uprave tih društava vodi poslove društva na vlastitu odgovornost dok nadzorni odbori imaju primarnu dužnost nadzora vođenja poslova. Nadzorni odbor raspolaže pravnim sredstvima kojima može pa i ključno utjecati na upravu i njezin rad, ali nije ovlašten na vođenje poslova.

Nadzorni odbor nadzire vođenje poslova pa treba biti uredno obaviješten barem o značajnijim radnjama koje uprava poduzima i o sveukupnom poslovanju društva. Nadzorni odbor može pregledavati i ispitivati poslovne knjige i dokumentaciju društva, blagajnu, vrijednosne papire i druge stvari, a uprava ga mora izvješćivati o poslovnoj politici i drugim načelnim pitanjima budućeg vođenja poslova društva, o rentabilnosti poslovanja te o tijeku poslova i o poslovima koji bi mogli biti posebno važni za rentabilnost poslovanja i za likvidnost društva. Nadzorni odbor može u svako doba tražiti od uprave da ga izvijesti o pitanjima koja se tiču poslovanja društva i koja značajnije utječu ili se razumno može očekivati da bi mogla utjecati na položaj društva.

Nadzorni odbor također utječe na vođenje poslova društva putem ovlasti da imenuje i opoziva članove uprave. Odluka o imenovanju člana uprave kojega je imenovao nadzorni odbor može se opozvati samo zbog važnog razloga.

Nadzorni odbor može sazvati glavnu skupštinu, a to mora učiniti ako tako nalaže dobrobit društva. Tako nadzorni odbor može potaknuti donošenje odluke koja spada u nadležnost glavne skupštine. Spomenutim pravom nadzorni odbori rijetko se u praksi koriste jer će najčešće uprava koja je u sukobu mišljenja s nadzornim odborom i sama sazvati skupštinu da bi otklonila svoju odgovornost.

Nadzorni odbor ili glavna skupština mogu dati suglasnost upravi za obavljanje određenih poslova, ali ta suglasnost ne može zamijeniti radnju vođenja poslova društva koju bi uprava trebala obaviti na temelju te suglasnosti. Poslovi uprave za koje je potrebna suglasnost nadzornog odbora mogu se utvrditi statutom, poslovnikom o radu nadzornog odbora i/ili poslovnikom o radu uprave koji donosi nadzorni odbor ili posebnom odlukom nadzornog odbora. Kada odlučuje o davanju suglasnosti upravi, nadzorni odbor ima pravo na poslovnu prosudbu. Za poslovnu prosudbu nadzorni odbor mora raspolagati primjerenim informacijama što u svezi s nekim pitanjima nije jednostavno ostvariti. Tako kod sportskih dioničkih društava nadzorni odbor u pravilu daje suglasnost za transfere igrača. Novčana vrijednost usluge igranja fluktuira na tržištu pa je za oslobađanje članova nadzornog odbora kao i članova uprave od odgovornosti za štetu ključno to da mogu dokazati kako su svoju odluku donijeli s dužnom pozornošću i na temelju primjerenih informacija. 
Član uprave mora voditi sve poslove društva s pozornošću urednog i savjesnog gospodarstvenika, neovisno o tome je li mu za poduzimanje određenih poslova prema statutu ili odluci nadzornog odbora potrebna prethodna suglasnost nadzornog odbora (ili glavne skupštine). U svom radu uprava i nadzorni odbor mogu koristiti usluge stručnjaka, a smiju osnivati i posebna povjerenstva (komisije) koja im pomažu u obavljanju njihovih zadaća (povjerenstva za sportska, financijska, pravna i druga pitanja), ali oni ne mogu umjesto uprave odnosno nadzornog odbora odlučivati o pitanjima iz nadležnosti tih organa.

Iako nadzorni odbor daje suglasnost upravi za mjeru koja spada u poslovodstvo, time taj organ ne prisvaja njezine ovlasti, jer nije ovlašten inicirati niti poduzimati predmetne poslove iz djelokruga rada uprave. Suglasnost nadzornog odbora nema značaj obvezujuće upute za postupanje što postaje vidljivo u slučaju kada je uprava za neki posao dobila suglasnost uprave. Bez obzira na suglasnost, uprava može od tog posla odustati ako njegovo poduzimanje nije više u interesu sportskog dioničkog društva. Inicijativa za poduzimanje nekog posla i dalje pripada samo upravi, ona i dalje odgovara za vođenje poslova, a suglasnost nadzornog odbora za neki posao ne oslobađa je odgovornosti.

Uskratom suglasnosti ne sprečava se upravu da poduzme taj posao, ali time nastaje važan razlog za opoziv imenovanja članova uprave te za tužbu za naknadu štete protiv član(ov)a uprave. Za štetu koja društvu nastane iz poslova za koje je upravi potrebna prethodna suglasnost nadzornog odbora (ako su poslovi poduzeti na temelju te suglasnosti te ako su za štetu odgovorni i članovi nadzornog odbora), uz članove uprave, i članovi nadzornog odbora solidarno odgovaraju društvu.

\section{POWERS OF THE SUPERVISORY BOARD OF THE SPORTS JOINT STOCK COMPANY IN CONNECTION WITH THE SUPERVISION OF THE MANAGEMENT BOARD}

The Supervisory Board of the Sports Joint stock Companies acts as the representative organ of the shareholders between the General Meeting and the Executive Board: the General Meeting elects (or privileged person/shareholder simply names) the members of the Supervisory Board, and the Supervisory Board appoints the members of the Management. From this point of view, one could see the General Meeting as the supreme body of the company. But the Supervisory Board, in the carefully balanced interaction of the three bodies, known as a system of "checks and balances", also has considerable independence from the General Meeting. According to the organizational organization of the Joint stock Companies, the general meeting is not superior towards the two other organs. In particular, the Supervisory Board and its members are not subjects to any instructions from the General Meeting. Neither the election of a member of the Supervisory Board by the General Meeting nor the appointment of a Supervisory Board member by a shareholder (entitled to name his representative) constitutes an imperative mandate for those members. On the other hand, the option of dismissal, which is legally available at all times, as a rule ensures that the Supervisory Board members will not act against the wishes of the General Meeting. 
Management measures cannot be delegated to the Supervisory Board. However, it must be determined by the Articles of Association or by resolution of the Supervisory Board that certain types of transactions may only be carried out with the approval of the Supervisory Board. By this right, the Supervisory Board will not become an executive body, equal with the Management Board, even in the case of transactions requiring approval: it can neither undertake the transactions in question itself, nor can it instruct the Executive Board to carry them out. The initiative remains with the Executive Board, which, even with the approval of the Supervisory Board, can still refrain from carrying out the business if it no longer considers it to be sensible and/or reasonable. The Management also remains fully responsible for the business with regard to liability; the approval by the Supervisory Board does not exempt them from an obligation to pay compensation for damages incurred. The Supervisory Board thus has the opportunity, by refusing its consent, to prevent the conduct of business intended by the Management Board.

Key words: Supervisory Board; powers of the Supervisory Board; responsibility of the Supervisory Board; Approval of management decisions; Sports Joint Stock Company 